\title{
CORTISONE AND ITS ANALOGUES IN ALIMENTARY DISORDERS
}

\author{
By S. C. Truelove, M.A., M.D.(Camb.), M.R.C.P. \\ Nuffield Department of Clinical Medicine, University of Oxford
}

The object of the present article is to discuss the uses and limitations of cortisone therapy in diseases of the gastro-intestinal tract, liver and pancreas. The term cortisone will often be used generically to embrace all forms of corticosteroid therapy, but it must be appreciated that the various steroids are not in every case interchangeable, and in particular that corticotrophin (ACTH) has different actions from natural or synthetic adrenal steroids used singly. ACTH often appears to be the most effective form of treatment but it induces marked clinical evidence of hypercortisonism and mental disturbances are relatively common. The synthetic derivatives, $\triangle$-cortisone (prednisone) and $\triangle$-hydrocortisone (prednisolone) appear to be somewhat more effective than cortisone in corresponding doses, but there is evidence that they are more prone to create or activate peptic ulcers, so that, frequently, it is best to start treatment with cortisone or hydrocortisone and hold the more potent preparations in reserve.

\section{Oesophagus}

Cortisone treatment has only limited applications in oesophageal disease. Its most important use is to prevent cicatricial stenosis of the oesophagus after the ingestion of corrosive substances (Dagradi and Stempien, I954), although some observers believe that it only slows, and does not prevent, the occurrence of stricture (Marchand, 1955). In a somewhat similar fashion, it can be used in conjunction with instrumental dilatation of fibrous strictures of the oesophagus to prevent or to delay recurrence of the stricture. In scleroderma, particularly in the form known as acrosclerosis, repeated courses of treatment appear to delay the onset of oesophageal involvement (personal observations).

\section{Stomach}

Cortisone has little application in stomach disease, other than the inhibition of excessive scarring after corrosive poisoning, which is analogous to its use in the oesophagus. Anti- biotics must be used in conjunction with it for this purpose.

The most important aspect of the stomach and duodenum in cortisone therapy is the liability that treatment itself may induce or activate a peptic ulcer, which in turn may give rise to haematemesis or perforation (Gray et al., I951; Sandweiss, 1954; Hirschowitz et al., 1955). Hence, cortisone should not be used in the presence of known peptic ulcer unless the need for its use is imperative. Simultaneous treatment with alkalis should then be used and can also be tried preventively in other patients receiving large doses of corticoids.

\section{Intestine \\ Steatorrhoea}

Both in coeliac disease in children and in idiopathic steatorrhoea in adults, cortisone will bring about rapid symptomatic improvement with increased fat absorption. However, in coeliac disease treatment has been radically improved during recent years following the discovery by Dutch workers that the subjects of this disorder are sensitive to gluten and that a gluten-free diet brings about normal growth and development. Cortisone should, therefore, be used only as a temporary measure in those patients, who, through delay in making the diagnosis or failure to adhere to a gluten-free diet, have become ill and difficult to bring under control by diet alone. In idiopathic steatorrhoea in adults, a gluten-free diet is sometimes; but not always, effective. Finlay and Wightman (1956) compared the effects of cortisone and a gluten-free diet in such cases, and found that cortisone rapidly relieved the diarrhoea and improved the absorption of fat. On the other hand, the response to a gluten-free diet, though more slow, was more complete. They regarded the two measures as synergistic. In adult cases, cortisone should be used only in those refractory to a glutenfree diet and it should then be combined with other conventional forms of treatment, namely, folic acid, iron, large doses of calcium and supple- 
ments of the fat-soluble vitamins. Adlersberg et al. (1953) consider that oral hydrocortisone (free alcohol) is the agent of choice in such cases.

Other forms of steatorrhoea are less helped. Thus Drenick et al. (1955) found no effect in cases of pancreatic steatorrhoea and steatorrhoea after subtotal gastrectomy.

\section{Regional Ileitis (Crohn's Disease)}

The use of cortisone has been studied by a number of observers (Machella and Hollan, I95I ; Kirsner et al., 1952). The consensus of opinion is well summarized by Zetzel (1956) in a recent review of the disease, in which he states: ' . . . these drugs may be followed by a dramatic remission in fever, diarrhoea and weight loss. This improvement is of unpredictable duration, but may be maintained in some cases by continued administration of small doses over a period of many months. Objectively, the roentgenographic appearance of the involved bowel does not reflect for some time, if ever, the favourable clinical response.'

\section{Intestinal Lipodystrophy (Whipple's Disease)}

This rare disease chiefly affects middle-aged men, who develop asthenia, weight loss, abdominal pain, steatorrhoea, arthritis, and pigmentation of the skin. Chronic cough and low-grade fever are common, and generalized lymphadenopathy may occur. Diagnosis can be made only by finding the characteristic histological changes, either in peripheral lymph-nodes removed by biopsy, or by laparotomy with biopsy of mesenteric lymphnodes and of the intestine. The course is usually progressive with death occurring a few years after the onset. Recently there has been some evidence that $\mathrm{ACTH}$ and cortisone are beneficial, at any rate in some patients. Wang et al. (1956) reported a case in whom a prolonged clinical remission followed the use of ACTH therapy. They summarized the results in this and seven other reported cases treated with corticoids, showing that two were terminal and died early in treatment, two responded but were not followed up, and four were remaining in remission for periods of two to 20 months. Hunter and Ward (1957) have reported a further case going into remission with ACTH therapy, a remission which, at the time they wrote their article, had been maintained for six months since stopping treatment.

\section{Ulcerative Colitis}

This is the gastrointestinal disease in which cortisone has been most extensively used. A number of observers used cortisone and ACTH shortly after their introduction and most were impressed by the frequency with which clinical improvement occurred. However, other workerf were perturbed by the high incidence of complica气 tions. For example, Tulin et al. (1952) had thre colonic perforations among 17 patients treated witip ACTH, and they judged that this form of treat ment was too dangerous to use in severe attacks of the disease.

This issue was resolved by a 'blind,' controlle therapeutic trial carried out with the cooperation of physicians in five hospital regions (Truelove and Witts, 1954 and 1955). Both for first attacks of the disease and for relapses, cortisone proved tô increase the chance of a speedy clinical remission $\vec{\circ}$ The beneficial effect was particularly marked in:first attacks, a finding of considerable importance as it is known that these are commonly very severe (Rice-Oxley and Truelove, 1950; Wheelocis and Warren, 1955; Demole, 1956). At ever stage of severity of the illness the cortisonet treated patients had a more favourable outlook than the control patients. In other words, the degree of severity should not influence one's decision to use cortisone.

However, cortisone does not work well in al? patients and its use should normally be stopped if there is no improvement in about three weeks and earlier if there is actual deterioration. It is hardly necessary to add that its use does not solve the physician from applying all the usiapo medical measures-blood transfusion, maint ance of water and electrolyte balance, adequates food intake, including much protein, and vitamin supplements-without which a patient cannot longू survive a severe attack. Cortisone appears some $\frac{\mathbb{}}{2}$ what to increase the chance of secondary pyogenic complications and should be combined with sys-은 temic penicillin and a non-absorbable sulphonamide by mouth; broad-spectrum antibiotics are? best avoided as a routine, and, if used, should be given in short courses of a few days only. ACTHE. is possibly more effective than cortisone and shoulds be tried if cortisone is ineffective.

A warning against persisting with cortisone if aô beneficial response is not quickly obtained has been given by Brooke (1956), who described three? patients, who, at laparotomy, showed an exces- $\rightarrow$ sively friable colon, with actual disintegration in places, which he regarded as a new phenomenon to be attributed to the treatment and one seriouslyo prejudicing the success of surgery. While all would agree with his general statement that cor- N tisone should not be continued indefinitely in the absence of a good clinical response, it must beo pointed out that such colonic changes have been described in the absence of cortisone therapy. We should also remember that a surgeon who has devoted himself with conspicuous success to the treatment of ulcerative colitis is likely to see more? 
than his fair share of medical failures. While on the subject of surgery in relation to cortisone, one important consideration must be mentioned. If a patient receiving cortisone needs urgent surgical treatment, it is a great mistake to stop giving him cortisone, for his own adrenal glands may fail to respond vigorously to the stress of the operation, with disastrous consequences. Cortisone should be continued, even at an increased level, until a few days after the operation, when it can be reduced gradually.

Quite apart from the controlled trial already mentioned, there is evidence that when cortisone is used more or less routinely the results are satisfactory. Thus, a group of workers in Chicago have reported favourably on the effect of cortisone therapy in 180 ulcerative colitis patients (Sklar et al., 1957). In the United Oxford Hospitals, there has been a marked improvement in the prognosis of patients since this form of treatment became generally used. Thus, among first attack cases, which used to carry a considerable hospital fatality rate, there has been no death in the past three years and only one has come to ileostomy.

It is unfortunate that successful treatment with cortisone of one attack of the disease does not render the patient free from the risk of recurrence, although immediate relapse is unusual. Longterm treatment can be carried out to avert this (Wirts and Rehfuss, 1956). This carries the risk of complications due to such long-continued treatment and, in general, it seems best to treat successive attacks as they arise. However, personal experience of a number of patients under continuous treatment for periods of a year or more without complication, leads to the conclusion that the risk is not very great provided the patients are under regular supervision.

An alternative approach to treatment is to apply hydrocortisone directly to the inflamed colonic mucosa by means of a nightly rectal drip (Truelove, 1956 and 1957). This treatment has been used in the less severe attacks and has produced very rapid remission in about two-thirds of the patients treated. It is best to use a water-soluble compound, such as hydrocortisone hemisuccinate sodium. With this agent, clinical remission is accompanied by histological improvement in the colonic mucosa. Local treatment does not protect the patient from further attacks, but it is usual for a patient who has once responded to this form of treatment to do so again. The method is at present being assessed under controlled conditions.

In brief, therefore, cortisone has been shown to improve the immediate prognosis of ulcerative colitis, but its effect on the long-term prognosis of the disease must still remain problematical for an obvious reason-namely, that sufficient time has not yet elapsed to permit assessment.

\section{Liver}

Cortisone does not feature prominently in the treatment of liver diseases, but there are some indications for its use.

\section{Viral Hepatitis}

Early reports on the use of cortisone and ACTH were encouraging, because the symptomatic response was good and the jaundice declined swiftly. However, controlled studies by Evans et al. (1953) showed that, although patients treated with ACTH had a prompt drop in the serum bilirubin compared with the controls, complete clinical and biochemical recovery was delayed and there was an increased chance of relapses occurring. With cortisone, a prompt fall in serum bilirubin was obtained and clinical recovery was faster than in the controls, while biopsy studies showed that liver healing was also accelerated although accompanied by severe, fatty metamorphosis. However, the cortisone-treated cases were more prone to relapse than the controls. A more favourable picture was found by Huber and Wiley (1955) in an extensive study of the effect of cortisone, in that the cortisonetreated patients did better in every way than the controls.

Viral hepatitis is usually a mild, self-limited disease with a very low fatality rate. Cortisone should, therefore, not be used as a routine measure, in view of the findings of Evans et al., which are supported by those of some other workers.

An exception must be made for those patients who develop hepatic coma as a complication of viral hepatitis. This is a most dangerous event, and most patients die. Ducci and Katz (1952) reported recovery, after treatment with cortisone, in two consecutive cases of fulminant hepatitis in young people, remarking that, in their large experience with acute hepatitis, they had not previously seen recovery after coma. Both patients made a spectacular response to treatment after being comatose for more than 48 hours and regained entirely normal health. Benavides et al. (1955) treated 16 children who developed deep coma in the course of viral hepatitis. The essential elements in treatment were ACTH, glutamic acid and glucose. Four patients recovered, this being attributed 'partially to the combined action of corticotrophin and glutamic acid which exert a favourable influence on the mobilization and utilization of glucose.'

In view of these findings, cortisone treatment may also be indicated in patients with viral hepatitis which becomes severe, so that the physician judges that coma is threatening. This is 
particularly likely to be the case in homologous serum jaundice, which in some outbreaks has been very dangerous.

\section{Cirrhosis of the Lizer}

Cortisone exerts a favourable influence on the symptoms of cirrhosis but, according to Winkler and Tygstrup (I957), it is doubtful if the course of the disease is much changed.

However, French workers in particular have observed highly-beneficial effects on the ascites which so often accompanies cirrhosis, at any rate in a proportion of the patients. Cattan and Vesin ( 1957 ) have summarized their extensive studies on this relationship. In all, they treated 32 cirrhotics with ascites, using prednisone as the therapeutic agent. In I 4 patients there was rapid relief of the ascites, and the 'assèchement' (dryness) was maintained after stopping treatment. In four more patients there was relief during treatment, although the ascites subsequently returned, either during treatment or after stopping it. In the remaining $\mathrm{I} 4$ patients, the treatment was a complete failure. They suggest as one possible cause for the good responses that prednisone inhibits the hypersecretion of aldosterone. A series of papers delivered at a meeting in Lyons support Cattan and Vesin's findings (Société de Gastro-entérologie de la Région Lyonnaise, 1956).

The value of cortisone in hepatic coma due to cirrhosis is problematical. On the one hand, there are physicians who believe it to be beneficial (Spellburg, I957). On the other, Sherlock, whose own work on the treatment of hepatic coma is well known (Sherlock et al., 1956) comes to the following conclusion:

' The evidence favouring the use of ACTH and cortisone in hepatic coma has not been convincing. Corticoid hormones are not recommended for hepatic coma occurring in patients with cirrhosis. In patients where the syndrome complicates virus hepatitis, recovery is so rare that cortisone or preferably the newer prednisone may be tried.' (Sherlock, 1957.)

\section{('holangiohepatitis}

Sborov et al. (1954) obtained highly beneficial results with $\mathrm{AC} \Gamma \mathrm{H}$ in a group of six patients suffering from cholangiolitic hepatitis, which had lasted for periods of up to six months, and was stationary or progressive when treatment was begun. All showed prompt improvement and recovered uneventfully.

\section{'Lupoid Hepatitis'}

'This is the name proposed for active chronic hepatitis associated with the presence of 'L.F. cells' in the circulating blood, a condition which predominantly affects young females (Bearn et al. $\vec{Q}$ 1956; Mackay et al., I956). Mackay et al. sugges ڤૂ that destruction of the host's liver cells causes anto-immunization, with consequent chronic des $\frac{\mathbb{D}}{2}$ truction of liver cells, and progression to cirrhosis? 'If this is so, it would be rational to use therapeutic measures (e.g. cortisone therapy) designed to? modify this process, and our experience suggests? that cortisone is of benefit. . . '

\section{Chlorpromazine Faundice}

Numerous reports testify to the frequencyes with which jaundice complicates chlorpromazine therapy, about 2 per cent. of the patients beingaffected. The condition has been thought to bew an allergic cholangiolitis. In most instances tho jaundice fades soon after stopping treatment, bu in some the jaundice persists for many months and there have been some deaths. Cortisone may bring about a dramatic response (Stein and Wright, 1956). A similar type of jaundice mav occur, though less commonly, with a number of్ర్ drugs, such as methyltestosterone, thiouracil, sulo phonamides and para-amino benzoic acid deriva? tives.

\section{Pancreas}

Cortisone is of little use in pancreatic diseage $\vec{C}$ but an exception may possibly be made for acte pancreatitis, in which cortisone was first repordo as beneficial by Stephenson et al. (1952). Rogस्rs et al. (1956) reported their observations on sis patients, all of whom made a good recovery. The remark: ' . . . it seemed that two at least of oug patients were likely to die, and that a rapid im $\vec{F}$ provement dated from the administration of cor응 tisone. Of the other four patients it can only be said that their recovery was rapid, but such re? covery could have taken place in patients not so treated .... This method of treatment appears to. merit careful consideration as a potentially bene $\bar{\sigma}$ ficial therapy for a condition which can be refrac tory to any treatment and is often fatal.' 'Th\&్ necessity for precise diagnosis before such a treat $₹$ ment can be contemplated is obvious.

\section{BIBLIOGRAPHY}

II) ERSBERG; D COLCHFR, $\mathrm{H}$, and WANG, Arch. intern. Med., 92, 615.

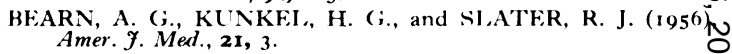

HENAVIDF.S, I.., KUMATE, J., PEREZ NAVARE'TTE, J. I.N SAGAON, J., and CARIIIIO, J. (1955), Paediatrics, 15, 586. BROOKE, B. N. (1956), Lancet, ii, 1 I 75 .

('A'T'TAN, R., and VESIN, P. (r957), Sem. Hóp. Paris, 33, 76. I)A(;RADI, A. E., and STFMPIEN, S. J. (1954), (alif. Med 81, 33 .

DEMOLE, M. (1956), Gastroenterologia (Basel), 86, 608.

I)RENICK, E. J., HVOLBOLL, F., and HAI SSTEL, J. A. (1955) New Eingl. F. Med., 253, 303.

I) ICCI, H., and KATZ, R. (1952), (jastroenterology, 21, 357.

Bibliography continued on page 346 
DURAND, O. H., FLORY, C. M., and HALL, W. S. (1955), New Engl. F. Med., 252, 1038.

EISENMENGER, W. J., SLATER, R. J., and BONGIOVANNI, A. M. (1952), Amer. F. Med., 13, 27.

FARBER, S., SHWACHMAN, H., TOCH, R., DOWNING, V., KENNEDY, B. H., and HYDE, J. (1950), ' Proc. rst Clinical ACTH Conf.,' p. 328 , Churchill, London.

FESSAS, P., WINTROBE, M. M., THOMPSON, R. B., and CARTẄIGHT, G. E. (1954), Arch. intern. Med., 94, 384.

FRENKEL, E. P., SHIVER, C. B., BERG, P., and CARIS, T. N. (1956), $\mathfrak{f}$. Amer. med. Ass., 162, 885 .

GENDEL, B. R., YOUNG, J. M., and KRAUS, A. P. (1952), Amer. F. Med., 13, 3

GEPPERT, L. J., AKEROYD, J. H., and SIMPSON, J. W. (1953), Pediatrics, 12, 72.

HART, F. D., WRAITH, D. G., and MANSELL, E. J. B. (1952), Brit. med. F., i, 1273 .

HAYHOE, F. G., and WHITBY, L. (1955), Brit. F. Haemat., I, I.

HENCH, P. S., KENDALL, E. C., SLOCUMB, C. H., and POLLEY, H. F. (1949), Proc. Mayo Clin., 24, I8I.

HILL, J. M., and HUNTER, R. B. (r95I), 'Proc. 2nd Clinical ACTH Conf., p. 181 , Churchill, London.

HILLS, A. G., FORSHAM, P. H., and FINCH, C. A. (1948), Blood, 3, 755 .

HOCHMAN, A., and ICKOWICZ, M. (1954), Brit. F. Radiol., 27, 467.

HUNTER, O. B. (1954), F. Amer. med. Ass., 154, 905.

LAURIN, J. G., BEAUREGARD, J. M., and PROVOST, G. (1957), Canad. med. Ass. F., 76, 296.

LEVINE, B., and ROSENBERG, D. V. (1954), Ann. intern. Med., 41, 844 .

LOEB, V., MOORE, C. V., and DUBACH, R. (1953), Amer. 7 . Med., 15, 499.

MACKAY, I. R., ERIKSEN, N., MOTULSKY, A. G., and VOLWILER,' W. (1956), Ibid., 20, 564 .

MCMILlAN, J. S. (1951), Amer. F. med. Sci., 222, 392.

MANDEL, W., MARILLEY, R. J., and GAINES, L. M. (1955) f. Amer. med. Ass., 158, 1021.
MEACHAM, G. C ORBISON, J L, HEINLE, R. W., STEELE H. J., and SCHAEFER, J. A. (I95I), Blood, 6, 706.

MEYER, L. M., and RITZ, N. D. (1954), F. Amer. med. As尺

MOREY, D. A., WHITE, J. B., and DAILY, W. M. (1956 Arch. intern. Med., 98, 821 .

M.R.C. Panel on Haematological Application of ACTH and Cortisone, Preliminary Report (1952), Brit. med. $\mathcal{F}$., i, 1261 .

M.R.C. Panel on Haematological Application of ACTH ary Cortisone, and Report (1953), Ibid., ii, 1400.

M.R.C. Panel on Haematological Application of ACTH arf Cortisone, 3rd Report (1955), Ibid., ii, 455.

MURRAY, J. F., RABINER, S. F., and KABAKOW, B. (I957) Ann. intern. Med., 46, 387.

NABARRO, J. D. N., STEWART, J. S., and WALKER, (1955), Lancet, ii, 993.

ROBSON, H. N. (1954), Med. F. Aust., I, 516.

STEFANINI, M., and MARTINO, N. B. (1956), New Engl. 7 Med., 254, 313 .

THOMPSON, M., SINCLAIR, R. J. G., and DUTHIE, J. J. $\dot{R}$ (1954), Brit. med. ., i, 899 .

THORN, G. W., FORSHAM, P. H., PRUNTY, F. T. G., an HILLS, A. G. (1948), f. Amer. med. Ass., 137, 1005. خे

THORN, G. W., FORSHAM, P. H., FRAWLEY, T. F., HILIO S. R., ROCHE, M., STAEHELIN, D., and WILSON, D: (1950), New Engl. Y.' Med., 242, 824 .

VIRKKUNEN, M. (1952), Arch. intern. Med., 90, 580.

VOLPE, R. BRUCE-ROBERTSON, A., FLETCHER, A. A an CHARLES, W. B. (1956), Amer. $\mathcal{F}$. Med., 20, 533.

WALD, N., and KISSIN, M. (1955), F. Amer. med. Ass., 159, 20.

WINTROBE, M. M. (1956), 'Clinical Haematology,' p. 98\$్రు Kimpton, London.

WINTROBE, M. M., CARTWRIGHT, G. E., PALMER, J. GO KUHNS, W. J., and SAMUELS, L. T. (I95I), Arch. intern. Med., 88, 310.

WIRTSCHAFTER, $Z$. T., GAULDEN, E. C., and WILLIAM. D. W. (1956), Arch. Derm. Syph. (Chicago), 74, 302.

Bibliography continued from page 334-S. C. Truelove, M.A., M.D.(Camb.), M.R.C.P.

EVANS, A. S. SPRING, H., and NELSON, R. S. (1953), Ann. intern. Med., 38, I I I 5 , I 134 , and 1148 .

FINLAY, I. M., and WIGHTMAN, K. J. R. (1956), Ibid., 45, 191. GRAY, S. J., BENSON, J. A., REIFENSTEIN, R. W., and SPIRO, H. M. (1951), Ұ. Amer. med. Ass., 147, 1529 .

HIRSCHOWITZ, B. I., STREETEN, D. H. P., POLLARD, H. M., and BOLDT, H. A. (r955), Ibid., 158, 27.

HUBER, T. E., and WILEY, A. T. (1955), Ann. intern. Med., 42, IOI I.

HUNTER, R. C., and WARD, J. R. (1957), Amer. F. dig. Dis., New Series, 2, 388.

KIRSNER, J. B., PALMER, W. L., and KLOTZ, A. P. (1952), Gastroeneterology, 20, 229 .

MACKAY, I. R., TAFT, L. I., and COWLING, D. C. (1956), Lancet, ii, 1323.

MACHELlA, T. E., and HOLLAN, O. R. (I95I), Amer. F. med. Sci., 221, 501 .

MARCHAND, P. (1955), S. Afr. med. F., 29, 195

RICE-OXLEY, J. M., and TRUELOVE, S. C. (1950), Lancet, i, 663.

ROGERS, N. C., WILSON, A. O., MEYNELL, M. J., and COOKE, W. 'T. (1956), Ibid., 2, 6'51.

SANDWEISS, D. J. (1954), Gastroenterology, 27, 604.

SBOROV, V. M., GIGES, B., PLOUGH, I. C., and MANDEL, W. (1954), $\mathscr{F}$. Lab. clin. Med., 43, 48.

SHERLOCK, S., SUMMERSKILL, W. H. J., and DAWSON, A. M. (1956), Lancet, ii, 689 .
SHERLOCK, S. (1957), Amer. 7. dig. Dis., New Series, 2, 353. SKLAR, M., KIRSNER, J. B., and PALMER, W. L. (1957) Ann. intern. Med., 46, I.

SOCIETÉ DE GASTRO-ENTÉROLOGIE DE LA REGIONं LYONNAISE (1956), Arch. Mal. Appar. dig., 46, 214, et seq SPELLBURG, M. A. (1957), Gastroenterology, 32, 616.

STEIN, A. A., and WRIGHT, A. W. (1956), f. Amer. med. Ass.오 16I, 508 .

STEPHENSON, H. E., JR., PFEFFER, R. B., and SAYPOI G. M. (1952), Arch. Surg., 65, 307.

TRUELOVE, S. C. (1956), Brit. med. F., ii, 1267.

TRUELOVE, S. C. (1957), Ibid., i, 1437.

TRUELOVE, S. C., and WITTS, L. J. (I954), Ibid., ii, 375.

TRUELOVE, S. C., and WITTS, L. J. (1955), Ibid., ii, 104I.

TULIN, M., KERN, F., JR., and ALMY, T. P. (1952), J. AmerG med. Ass., 150, 559

WANG, C. I., JANOWITZ, H. D., and ADLERSBERG, D. (1956) Gastroenterology, 30, 475 .

WHEELOCK, F. C., and WARREN, R. (1955), New Engl. F. Med. 252, 421 .

WINKLER, K., and TYGSTRUP, N. (1957), Acta med. scand.) I57, 149 .

WIRTS, C. W., and REHFUSS, M. E. (1956), Gastroenteralogia (Basel), 86, 689.

ZETZEL, L. (1956), New Engl. F. Med., 254, 990, and roz9.

.

